\title{
壁䱊 日本鐵鋼協會第拾八问講演大會
}

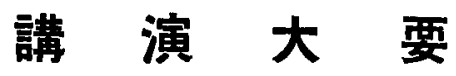

1）電氣爐銑のニミの性質に就て

日立製作所戶畑工場技師：工學士 杉 正 道

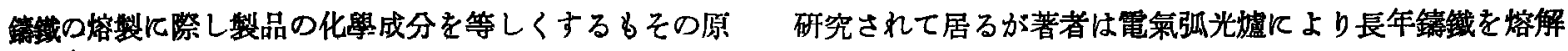
料丈は揢解處理の如何により其の物理的性货の上に非常な せる經驗より その熔解方法の差異及材料の變化により如

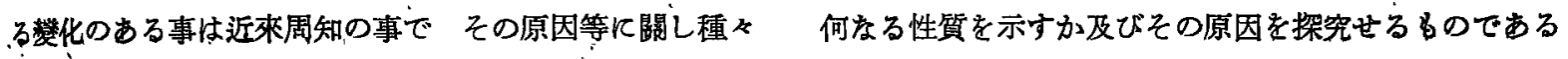

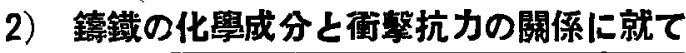

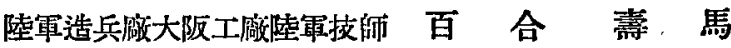

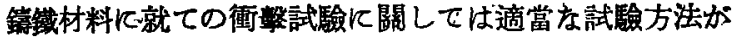
知られてるないためか一般に餘り關心を持をれてるない樣 でする 然し物によっては衝擊抗力が他の抗張力や抗折力 亿劣ら才重要視されねばならね場合がある 鋞物彈の如き

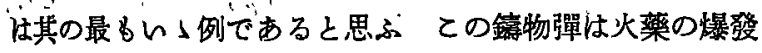
によって瞬時に起る强力な㰮力のために砲身から兆出すの であるからその材質はての衝撃に對して充分安全なるので なくてはならぬ 然るに初めから之に適する衝撃抗力の優
れそ材料を得ると云ふ事は從來の例によって見るる決して 容易ではない 之は衝瞖抗力が抗張 抗涯力に比例して增 减しないで化學成分との間に別の關係を有するからである 筹者は 10 數年間陸軍で使ふ鑄物彈の製造得事してなる 關係上多數の材料に就て試驗をした その結果より鑄鐵の 衝擊抗力之抗張力 抗涯力之の關係及化舉成分之之等金質 徽數との關係を探究し鋞物彈に適當なる慗造方案を作つた ので之を發表しに諸賢の御化正をとふ次第である

\section{3）、銡銅用生型砂の配合に對する基碮理論に就て}

大同電氣㓟鋼所熱田工場 工學士吉 田 正 夫

鑄物に對し鑄物砂の重大影響ある事は今今更言を要しない 最近本邦に於てる此が研究盛となり既に数名の人により其 研究結果が發表されてるる 而して此が研究に對して其影 響する因子餘りに數多なる赤め其實驗結果に相當大なる誤 差を認め未だ實用性充分なりとは言ひ得ない 著者は條件

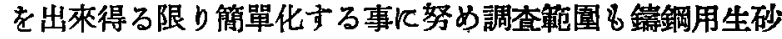
に極限し實驗結果を基礎とし配合に對し基礎となる點を理 論的に考察して見た 第 1 報は鑄物砂の主成分たる珪砂 粘土 水分の常溫に於ける相關關係第2 報は粘結物質の 常溫及び高溫に於ける性質を比較考察した

\section{4）モリフテン鑄鋼の製造法に就て}

橫須賀海軍工成 海軍技師 西 武 雄

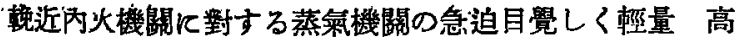

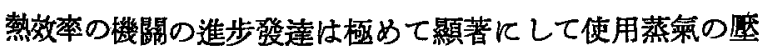
力涉住溫度は念速に高められつ」あり從て其の使用鑄物材

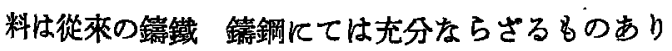

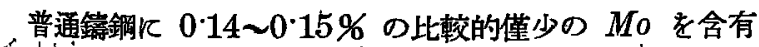
努しむる事に能り $400 \sim 600^{\circ} \mathrm{C}$ の高盢度に於ける强度の
降下涉に匍匋儿徏る變形を著しく減少せしめ得

此の點より本材料を此の溫度程度に於て使用する锚鋼材 料として推獎す

其の製造法の太要 殊に䒸基性孤光電氣爐による Moの 源加熔解法涉に鑄造品の熱處理に就き大繁を述へんとす

\section{5）大型鑄鋼品鐥造法の研究}

近時各種工業の發達に伴ひ諸機械設備は何れる大規模大 騥力ののが盛に設計せられることとなった
日本彆鋼所空蘭製作所 結 城 你 治

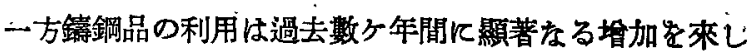
必然的に大型鑐鋼品を要求せらるる機會が多く其の鋀造成 
績の良否が其等の㙨峨設備の能率に及ばす影響も亦齿くな n.

日本製鋼所室蘭製作所は既往約 30 ケ年間に涉り各種の

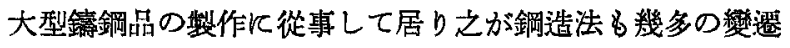
を經て今日に至て居る

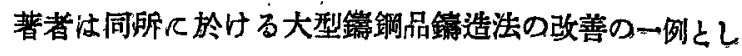

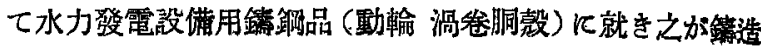
法の變遷之之に伴ふ制品の改言狀況を實例を舉げ、論远し 將來此方面の研究に資する一端たらしめんとするものです る

\section{6）鐵鋼分析に於けるスペクトログラフの應用}

發光スペクトルルよって精菜なる定量分析を行ふ事は非 鐵合金の場合の例は多少報告せられてるるが鐵鋼の場合の 例は甚だ少い 著者は火花放電に依り特殊鋼中の

$M n, ' S i, C r, N i, C o, W, M o, A l, T i, V, C u$ 谷析法につレて研究し 2〜3\%以下では誤差は大體

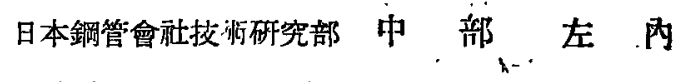

士.5\% 以下なる事を確めた

此の方法の原理 普通化學分析之の優劣 形狀不同の䋯料 をそのま」電極として用ひ得るために必要なスべトル線 の選擇放電狀況によるスペクトル線强度の變化等につんて 概略を迅べんとす（幻燈使用）

\section{7）硝酸による鐵及鋼の受働態に關する研究}

理化學研究所 理學士山本 洋 $\rightarrow$

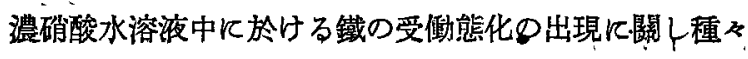

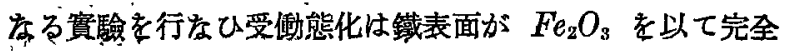
飞被覆される狀熊的んて起ることを確めた 而して活性 鐵面沉於ける $\mathrm{FeO}$ 唯 $\mathrm{Fe}_{2} \mathrm{O}$ : 飞まで酸化されるに際して は鐵面に於々て發生機酸素の生成を必要とすることを推定 し 受働態化飞於ける基礎的化學反應として次の 2 つの式 を樹てる゙てとができだ

$$
\begin{aligned}
& \text { (1) } \mathrm{Fe}+\mathrm{HNO}_{3}=\mathrm{FeO}+\mathrm{HNO}_{2} \\
& \vdots \mathrm{FeO}+2 \mathrm{HNO}_{3}=\mathrm{Fe}\left(\mathrm{NO}_{3}\right)_{2}+\mathrm{H}_{2} \mathrm{O} \\
& 2 \mathrm{Fe}\left(\mathrm{NO}_{3}\right)_{2}+4 \mathrm{HNO}_{3}=2 \mathrm{Fe}\left(\mathrm{NO}_{3}\right)_{3}+2 \mathrm{HNO}_{2}+\mathrm{H}_{2} \mathrm{O}+\mathrm{O} \\
& \quad 2 \mathrm{FeO}+\mathrm{O}=\mathrm{Fe}_{3} \mathrm{O}_{3}
\end{aligned}
$$$$
\text { (2) } 2 \mathrm{Fe}+2 \mathrm{HNO}_{\mathrm{s}}=2 \mathrm{FeO}+2 \mathrm{HNO}_{2}
$$

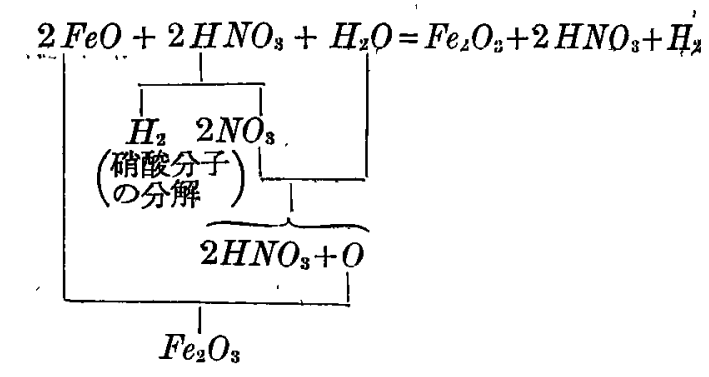

茲に此の 2つの式に對す予實驗的根據をのべ併せて碳酸 水溶液の電解汇於ける鐵陽極の受働態化 硝酸水溶液中、

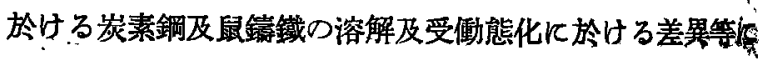
つレて論进する

\section{- 8）特許特柘耐蝕性合金銅に就て}

佳友金屬工業會社鋼管製造所 研究部員 大 倉 幸 雄

特許特殊耐蝕性合金鋼としての高 $\mathrm{Cr}-\mathrm{Mo}$ 鋼並飞高 $\mathrm{Ni}$ 性及機械的性質飞就き系統的飞研究也る結果を迅べれをす $C r-M o$ 鋼の高溫度耐酸化性 各種腐餒性媒介飞對する耐玲 るものなり

\section{9）特殊鋼の熱傳尊率に就て}

鋼の熱傳導率飞就いての研究は此較的少く殊に特殊鋼の 熱傳導率江就ては 工具鋼の熱傳導率の測定值が一二ある 位で殆んぞやって居らぬ 特殊鋼の熱處理 鉣鍊化際しての 加熱其他化於てその特殊鋼の熱傳導率を知る必要务可去り

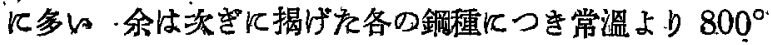
ゆ高溫意ての熱傳導率を测定した
日立製作所冶金研究所長 理學博士。菊 田 多利男

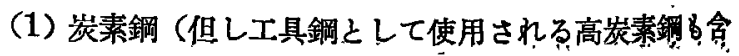
む)

3 種

(2) ニックル・クロム銅 2 㮔

(3) 不銹釦 2 種

(4). 高速度龬 2 㮔

（5）其他特殊工具銓， 
淇促の方法は本誌第 19 年第 1 號及び第 6 號(昭和 8 年) 潑表した「鋳鐵の熱傅導率に就て」の方法と全く同じで

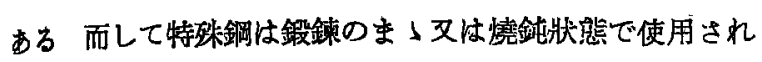
方事は隇多にないのであつて大抵は燒入燒戻の狀態て使用

10）鐵䤡中の含有瓦斯に關する砾究

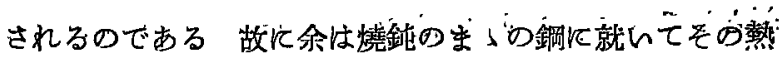

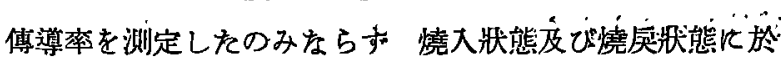
け当熱傳遒率をも測定した

\section{日本特瑟鋼會社技们 工學士 矢島 忠 和}

臷の水素吸收に就て行はれれ從來の貝驗は粉末狀の試料 を水素中にて加熱し 吸收せられるため反生晾る水素の減 量堂测定する方法儿伐て行はれた本研究に於ては $10 \times 13$ $\times 300 \mathrm{~mm}$ の角型の試料を水素中得加熱し 是を水中急 希して後 真空抽出法往より吸收せる水素量を定量した

上記抾の試料が水素を完全に吸收飽和する迄飞要する 時間は $A_{1}$ 變態點以上では 1 時間で充分である 然し低溫 度で社1時間乃至 4 時間を要する 水素中にて加熱して吸 收せしめを水素は常溫にて徐々に逸出する倾向を有するが
逸出する速度は極めて羧かで西るから急冷後速かに分析す れば正確なる結果を得る事が出來る：。

$\alpha$ 鐵の水素吸收は $400^{\circ} \mathrm{C}$ 上り認めら水溫度の上昇之共

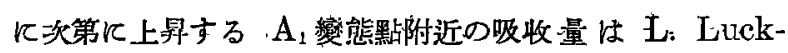
meyer-Haase 及 H. Scherrck の結果より低い值を示した が $\gamma$ 鐵の吸收量の溫度に上る增加は本實驗結果著して現 れた $N i$ 中の吸收量は前者の結果と $1,000^{\circ} \mathrm{C}$ 亿於て二 致したが低溫度にて高い値を示した

其の他 $C r$ 及 $S i$ を含有せる鐵に就ても同樣の實驗を行范

\section{1）滲岩平衡及鐵炭素狀態圖に就て}

淁炭現象を從來屠 $3 \mathrm{Fe}+2 \mathrm{CO}=\mathrm{Fe}_{3} \mathrm{C}+\mathrm{CO}_{2}$ をる式で 䒧して來えのは幛である $\mathrm{Mn}, \mathrm{Cr}, W$ 等の如く炭化物が安 定なる場合と異り $F e_{3} C$ が不安定な結晶であるから 上の

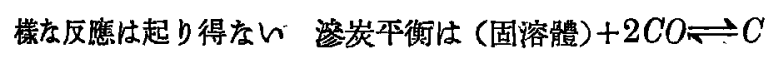
(固溶體) $+\mathrm{CO}_{2}$ なる式で表す可きである 固溶體が炭素に 侁て能和された場合には $2 \mathrm{CO} \rightleftharpoons \mathrm{C}+\mathrm{CO}_{2}$, 師ち $\mathrm{CO}$ の解

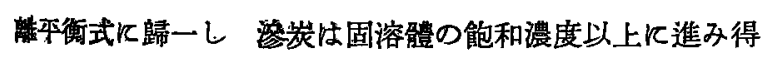

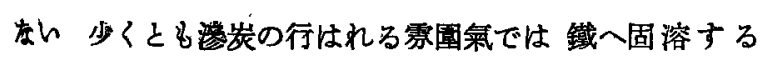
酸素の量は全く零と見做されるから 溶炭菜に於ける固相
理化學研究所 理學士 真殿統 は純粹の 鐵炭素二元系として报はれる 故に $2 C O \rightleftharpoons C+$ $\mathrm{CO}_{2}$ なる本衔之 $\mathrm{Fe}-\mathrm{C}$ 狀態圖を組合せる事に上り 溶炭系

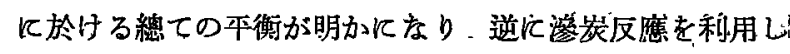
て正しい $F e-C$ 狀態圖か描かれる 此場合に结熱分析的 場合之異り過冷相である $\mathrm{Fe}_{3} \mathrm{C}$. が全く現れなり事は從來 色色之論議されて來た $F e-C$ 狀態圖飞對して重要な意味を 有してるる 鐵飞 $S i$ を加へを場合 及び熔鉎一の加㞸平 衡化いても述べるそして理論と實驗 及び實際の材料 銑鐵 鋼に就いて調べを結果が好く一致してるる事を示す、

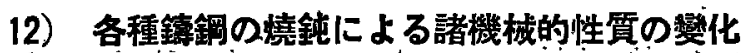

主として降伏點の本性に就て

芝浦製作所研究所工學博士，中．．村，..，素

工.學士．河.合成 治

炭素 $0.1 \sim 0.25$ 程度合有する普通䤢鋼並飞 $N i, C r$ 等, を合有する特殊鎊鋼を常溫より $1,000^{\circ} \mathrm{C}$ 迄各溫度飞加熱

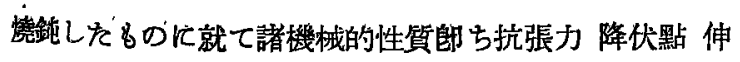

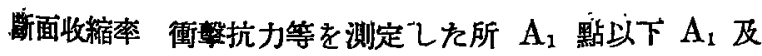

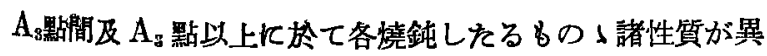

13）種々の狀態に於ける鋼材の磨耗に就て

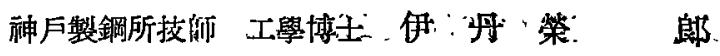

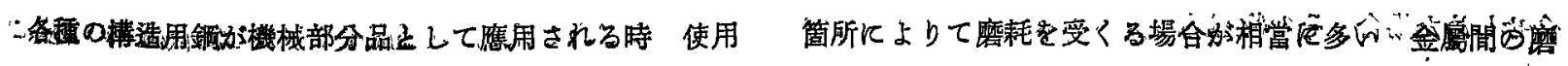


耗としてビストンリングとシリンダーライナー 軸と軸承 或はレールとタイヤー等の問題住餘りに有名にして從來多 くの人くによって研究されて來た所である 然し生库を目 的とする工業機械方面では金屬之非金屬物との磨耗が亦重 要なる問題として考へられて居るが之に關する研究恃本邦

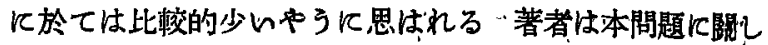
て既江數年前研究結果發表したが其後程かの場合を考虑 し更に多くの材料に就て磨耗試驗を行た

茲に報告せんとするは釦材の高溫度並びに常溫に於㚈、 耐磨耗性之之等鋼材の化學的性質の關係である

\section{4）戥留オーステナイトに關するニ 三の實驗}

牫留オーステナイトに就ては從來多くの人ねにより研究 せられて居る゙泠：却速度之殘留オーステナイトとつ量的 開係に就ては殆んど研究されて居ないはうである。

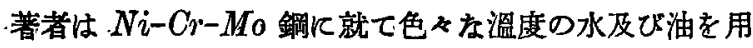
ひ燒入冷却速度を種々飞變へてその場合のオーステナイト の残留量を磁氣硬度及び $\mathrm{X}$ 線試驗に上って攻究し 次で 残留オーステナイトが鋼の機械的性質に及将す影響を調へ た
日本製鋼所空蘭慗作所阿 部 三 郎 その結果

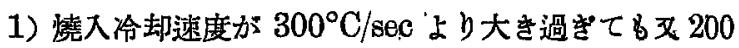
${ }^{\circ} \mathrm{C} / \mathrm{sec}$ 上り小さ過さてもとの殘留量汃少ない

2）焼㞍溫度がオーステナイトの分解溫度より低い場合 にはオーステナイトの钱留した方が衝慗值が大であ る 然し燒屃溫度がオーステナイにの分解し始めるや 了，な溫度儿なれば却て最初からオーステナイトを殘留 しない方分衙撃值が良好である

\section{5）ニッケルークロム銅の變態速度に就て}

東北帝國大學数授 理學博士 村上武次郎 '金屬材料研究所助，手'湯! 源! 精'一

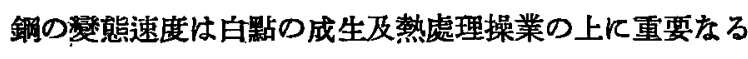
關係がある 而して其䇾態速度は鋼の組成及冷却保件飞依 て異をる・故炕 $N i \bullet C x$ 鋼の變態速度を知る目的を以て $\mathrm{Ni}, \mathrm{Cr}$ 及 $\mathrm{C}$ の組成異死る種々の鋼を造り種《の椧却保 件の下に冷却乙 熱膨脹の測定飞依て冷却速度之變態點及

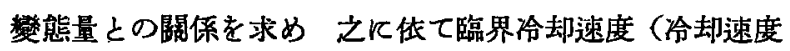

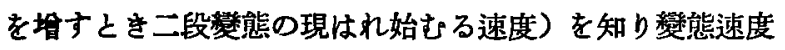
を決定しれ 又此等試料の椧却曲線を比較して次の事實を 知るととが出來た（1）同一鍋と於ては一定溫度より冷却
ナるときは冷却速度を增方炕從て A $\mathrm{r}^{\prime}$ 變態门量を減し $\mathrm{Ar}^{\prime \prime \prime}$

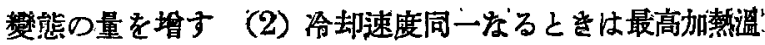
度が上昇するに從ひ $\mathrm{Ar}^{r}$ 秒態の量を減し臨界椧却速度文 は䙪態速度を減小す '(3) $\mathrm{Ni}$ 及 $\mathrm{Cr}$ 合量一定にして崖素

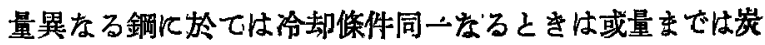
素量を增すと從て變態速度を減するが更儿炭素量を增すと

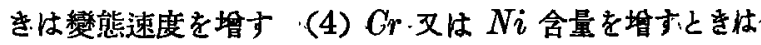
變態速度を減市

\section{6）桪成用特殊䤡材の物理的性質に及す $\boldsymbol{W}, M o, V$ の影響}

日立製作所冶金研究所長 理學博士 菊 田，多 利 男

同

ニッアル・クロム鋼 不銹鋼等の榙成材料用特殊鋼の機械 的性質並に變態點其他に及す $W, M o, V$ の影響に就ては 區々の研究は可成多く見られるが全體を系統的に調べたも のは比較的少々樣に思はれる 最近特に航空機材料用鋼之 して是等の特殊鋼に對する需要が旺となり進んでは現在の 陸海軍規格上より以上の强靶銓 要求せられると至たので その基礎的研究として先づ炏の各種の釦に對して $W ; M o$, $V$ の各䒕素を單獨に $0.1 \%$ 万至 $4 \%$ の範圍內で種々に配 合せしめを場合 その物理的性質が是等の元素により如何

$$
\text { 所工學士芥仃武 }
$$

に影響せられるかを攻究し虑:

(1) 炭素鋼

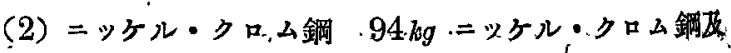
$160 \mathrm{~kg}=$ シ ル・ク.ムム銅

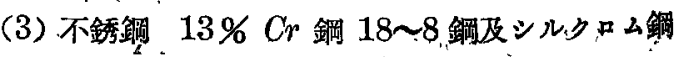
筫驗の方浩は弧光式電氣爐にて入念精鎮した原料銅材を

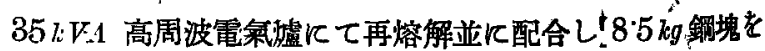

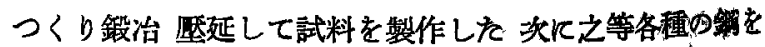

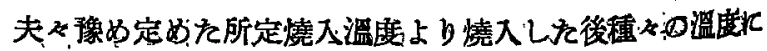




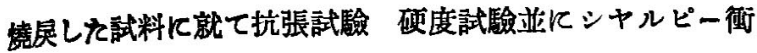

熱膨脹試驗及磁氣分析を行を

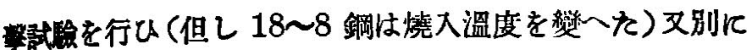

\section{7）熔接部の機械的性䨘に及ほす溫度の影暗に關する一考察}

Some study on the effects of temperature to the mechanical properties of the welded metals. 三荾重工業會社神戶造船所技 仰氏家竹次郎

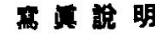

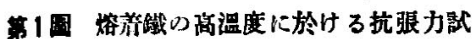
牌

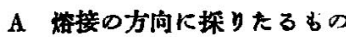

B 接の方向に遖㑇に探りたるるの

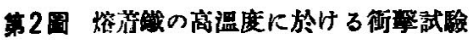
片

A 擦势の方向に探りたるもの

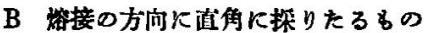

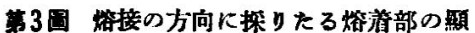

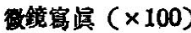

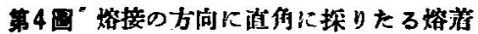
部斯微鏡笉暝 $(\times 100)$
(A) 茅 1 圖
(B)

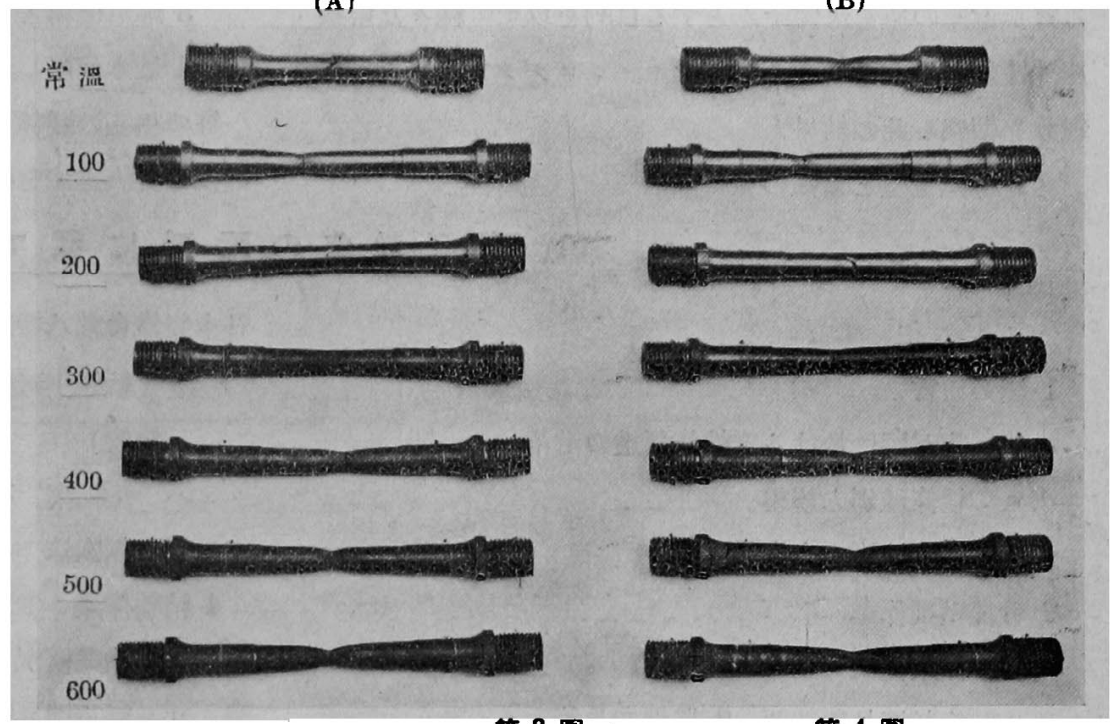

第 3 圖

第 4 圆

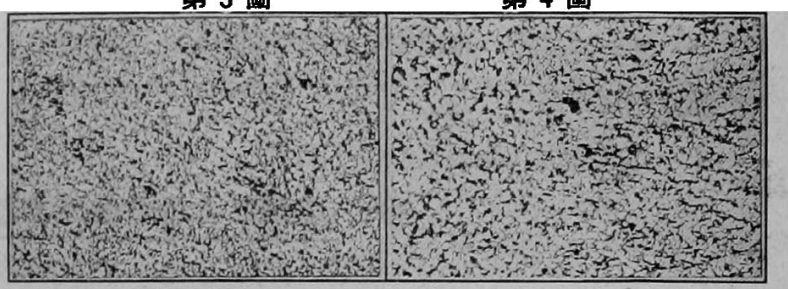

現在の電弧熔接に於て比較的廣範圍に使用せられつ〉す る軟鋼用被覆揢接棒の一種を以て製作しを揢着試驗片を探 り本研究のため特に準備せる試驗裝置を用ひて $100^{\circ} \mathrm{C}$ $200^{\circ} \mathrm{C}, 300^{\circ} \mathrm{C}, 400^{\circ} \mathrm{C}, 500^{\circ} \mathrm{C}$ 及び $600^{\circ} \mathrm{C}$ の各溫度に 於て實施したる抗張力（第 1 圖參照）及び衝撃抵抗（第 2 圖寥照）に對する實驗の結果を報告し 次で揢着鐵の常溫 より $600^{\circ} \mathrm{C}$ に至る間の熱膨脹を测定して 其の途中に於け る變化の有無を確むると共に 熔着鐵の化學成分（第 1 表）

第 1 表 焀葑鐵化學成分(\%)

$\begin{array}{cccccc}C & P & S & M n & S i & N_{2} \\ 018 & 0.028 & 0.015 & 0.83 & 0.06 & 0.022\end{array}$
之影微鏡組織（第 3 圖及び第 4 圖案熙）に就て檢討を行ひ 同時に熔着鐵の結晶粒が微細化せらるる理由を說明し 别 に聺着鐵のみから作を試驗片を $100^{\circ} \mathrm{C}, 200^{\circ} \mathrm{C}, 300^{\circ} \mathrm{C}$, $400^{\circ} \mathrm{C}, 500^{\circ} \mathrm{C}, 600^{\circ} \mathrm{C}$ の各溫度少ら水中飞燒入れして其 の硬度及び衝擊抵抗を测定することに化りて揢着鐵中に存 在する点素の影響を吟味し更らに熔着せる㑺並びに $600^{\circ} \mathrm{C}$ 及び $850^{\circ} \mathrm{C}$ に於て筧鈍せる熔着試驗片を夫ね $600^{\circ} \mathrm{C}$ 加 ら水中に燒入した場合に起る時效現象に就て一の教察を試 みをものである 
18）電弧熔接用被覆卿の奄弧現象に及ぼすニ三の特性(第二報)

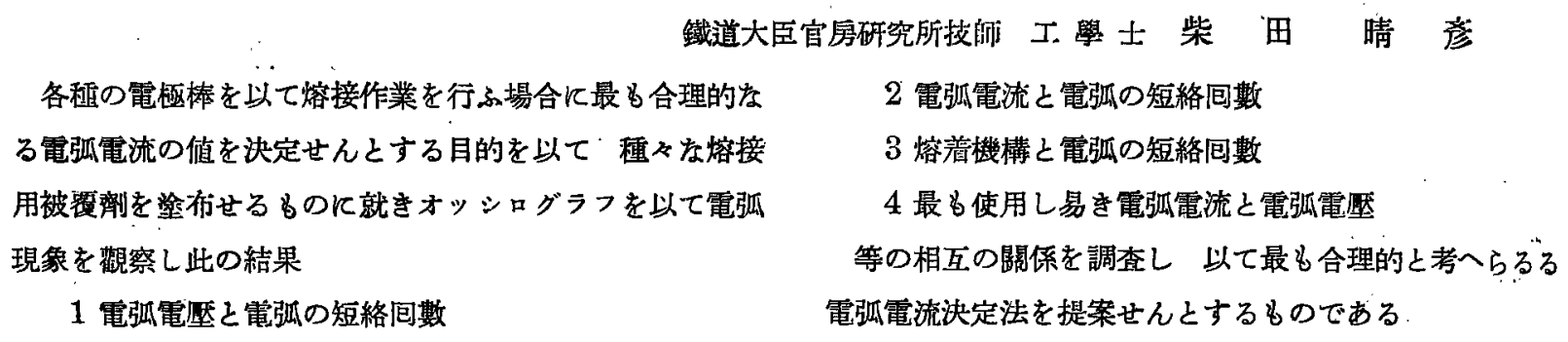

19）長尺軌條の涯延に就 て

1 緒 “言”

イ我が國に於ける重軌條製造の沿革

口“軌條種別之規格

八長尺軌佟の胄來

2 分塊㻺延作業

1 作業概沉（全體圖化依り說明）

口 均熱㠊加熱時間 瓦斯消費量等

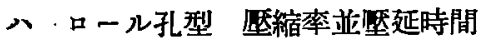

3 軌條㻺延作業

1 作業概況（全體圖化传り說明）
日本製鐵會社八幡製鐵所内恬

口 軌條塺延法（孔型種別に徒る特性口ール調整誘導 裝遀）

八壓縮率 孔型の變化並汇涯延時間

= 鋸断法

4 精整作業

1 作業概沫 (全體圖化倿り說明)

口 稫正機 端正機說明

八檢定積出

5 結 論

\section{0）腐蝕による重量減を基䃨 とする耐蝕性の決定に就て}

金屬材料の臂蝕が全面的に且つ均等に進行する場合に於 ける耐能性を定量的飞決定するる方法としては重量減を基礎 そするてとが最も好都合である

“現在重量減に上る耐刢性の記載の方法としては試驗片 の重量減を最初の表面棈を以て除し・單位表面積に於ける 減量を以てされるてとが普通である 然しながら此の方法 では比重を異にする金屬材料相互間の耐蝕性を比较するに
理化學研究所 理 學士山本 洋一

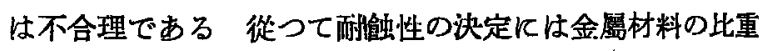

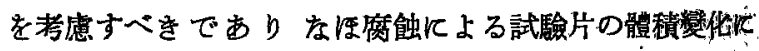
基因する表面積の變化に就ての補正が必要である、

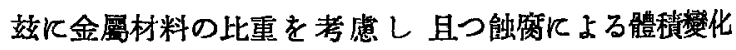
を補正せる耐蝕性の決定方法として 補正平均侵腐度疗る ぬのを提出しその意義を㗂酸水溶夜沉上る炭素銅及鼠 鐵の侵刢度につんて試驗せる結果を以て說明する

\section{1）砂鐵の直接製鋼に關する研究}

大阪工業試驗所技師、工學士传 野 正夫

演者は去る昭和 10 年 9 月命を帶びて本邦於て比䡆的 多量の砂鐵を埋藏する東北地方の砂鐵錦區を調查した“青 森縣下北郡大畑町字二枚橋附近產出の砂鐵愔黑色砂鐵にし て低燐且高バナデウム含有の優秀なる砂鐵なる事を發見し

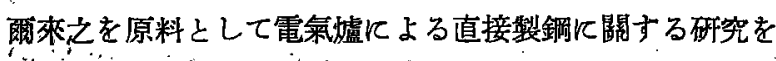
行つた 現在迄の研究結果を兹に報告する

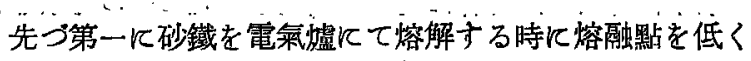

して流動性の良好吉万震涬を造る事を研究した 磁選した る砂鐵炕燒石灰 無烟炭 䖝石の割合を種そ變更して添加 し電気爐洼入して熔解し時々還元劑える無烟炭を投入し て整鍊し蛒解狀態の良好なる點を見出した

次にバナヂムの還元に關して研究し種く研究の結果慜

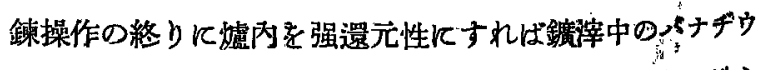

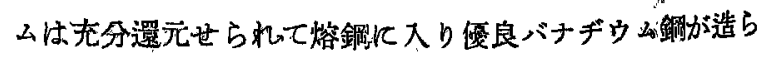


る」事を知た 研究䌘品の大體の成績は次の通りである

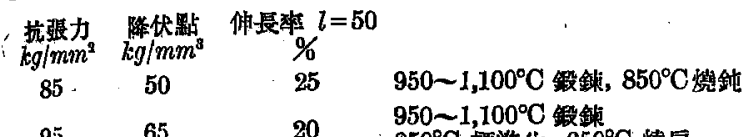

$95 \quad 65 \quad 20 \quad 850^{\circ} \mathrm{O}$ 標燋伦, $650^{\circ} \mathrm{C}$ 䙺杘

$(\mathrm{C} 0 \cdot 42 \% \mathrm{C} ; 0.25 \% \mathrm{~V})$
結論としては原料たる砂鐵は低燐砂鐵炊るため除燐の必要 なく一錿滓法によりて简單にバナダウム銅が造らるい故に その䌘鍊所要電氣量を低下する事が出來るのである“其製 鍊方法及消賏電氣量等に就いて詳細に迅ふ

22）酸性䎨氣爐操業成綪に就 $て$

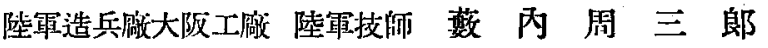

酸性電氣㠊操業に就ては暗て發表した（鐵と鋼 第23年 第2 號 117 頁）が其後引續き良好を成績で操業を繼續し て居るその成績の全部に就ては發表を許されて居ないが許
されを範圍に於て實際操業の統計的結果材質的成績涉几嘘 內化學變化等に就て述へ諸賢の參考化供したい考である

\section{3）製鋼過程に於ける龬中の水素及窒素に關する研究（第 2 報）}

蛒鎆中への水素浸入機構に就て

慜鈵過程に於ける水素合量の一般的變化と輕娍法の二三 に就ては前回に報告したが 今国は精鍊中に於りる水素增 加す主要原因が爐內瓦斯中の水分であるてとを實驗的に確 かめ進んでその浸入機構を說明せんとするものでする

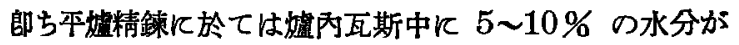
含有されて居てての水分が鋼㳯中に溶解して熔鋼に水素 を浸入せしむるもので 鋼㳯には $\mathrm{CO}, \mathrm{CO}_{2}, \mathrm{H}_{2}$ 及 $\mathrm{H}_{2} \mathrm{O}$
日本觀鋼所窒蘭觀作所 小 林 佳 三郎

の瓦斯が共存し $\mathrm{CO}+\mathrm{H}_{2} \mathrm{O} \rightleftharpoons \mathrm{H}_{2}+\mathrm{CO}_{2}$ なる反應平衡が成 立して居る 鋼涬中の $\mathrm{H}_{2}+\mathrm{H}_{2} \mathrm{O}$ の合量を增し且揢鋼中 の酸素が減少するに從ひ水素会量を增加するに至る

從て鋼中の水素を減する根本的對策は嘘內瓦斯中の水分 を無くすること及沸滕精鏉を行て溶解して居る水素を驅除 するてとである

\section{4）酸性製鋼法に於ける珪素の還元に就て}

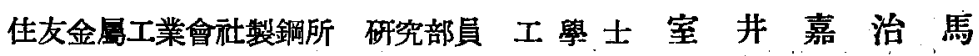

酸性㠊の製鋼反應に於て熔解中に珪素が還元されて來る や否やは 熔鋼中に $\mathrm{FeO}$ 少きか多きか 郎ち自然飞脫酸が 行はれをるや否やを示すものにしてヌ酸性平罏の場合に珪 素があま多量に還元さる」時は熔鋼中に $\mathrm{FeO}$ 非常に少 くか」る時には嘘ガスより水素が吸收され易く從て白點 の原因となる樣思はる」を以て 珪素の囬元度は製出さる 銈の品質に大いに影響する事柄なり。 此の方面の研究としては Koerber 及び Oelsen は砂 坩堝中にて砂の蔽の下に高炭素配合の鋼を熔解したる場合
の珪素の還元狀況を研究し Bardenheuer 及び Bottenberg 恎性高周波爐にて硝子性鋼漳の下Kて高炭素配合 の鋼を熔解したる場合に 珪素の還元に及ぼす溫度の影響 を研究せるも溫度の外飞鋼涬の化學成分及び其の量 熔落 の鋼の化舉成分及び爈の形狀並に容量等種々の因子の影響 を考ふる必要あり之思はる 本報告にては $50 \mathrm{~kg}$ の酸性高 周波爐を利用し 珪素の還元に對する熔解溫度及び鋼涬の 化學成分の影響を研究したる結果を迅べんとするものなり

\section{5）鋼の鑄込溫度に關する研究（第1 報）}

日本㓟鋼所室蘭製作所 理 學士 原。於 菟 雄

鋀込溫度が鋼塊の偏析や砂班认著しい影響を及ぼすもの であることは既によく知られて居るとてろである從て鑄 込中に劫ける温度變化を知り適當な鑄込溫度を探擇するこ くは浩塊，上頗る緊要な事唡であるが末犯正確な测定法によ
る詳しい實驗が行はれて居ない ようて著者は白金一白金 ロヂンーム熱電對を用ひ 3〜40 䣩鋼塊の鑄込中及鑄込後

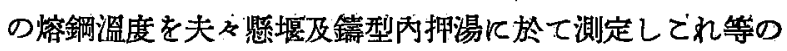

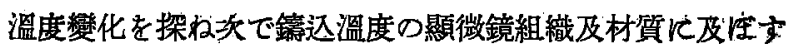


影響を研究した 今回は鋀込中及鎍达後の溫度變化飞就て 速べる

\section{結果の檄要}

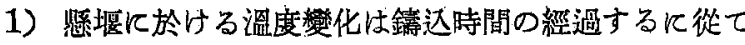
降下する場合 略一定の場合及.上崉する場合の 3 程類 がある

2）樏塸ノッズルの直徑を異らしめれぱ直徑の小となる 飞從ひ溫度降下が激しくなる

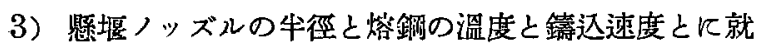
て次の關係賽驗式を導いた

$$
V=0.185 r^{2 \cdot 5} \log (\Delta t+1)
$$

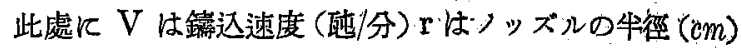

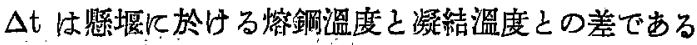

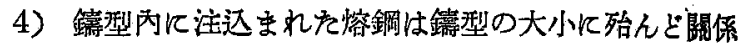
なく急速に溫度を降下して液相線に達する液相線儿

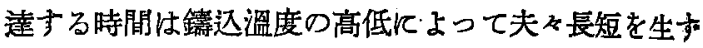
るが其の差は嚾小である

5）液相線に達して後此處に止る時間は躊达溫度の高い

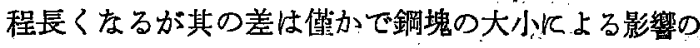
方が遥かと大である

\section{6）航空機用プロペラハブ用材の研究}

\section{任文金屬工業會社伸銅所 研究部員 堀慥爾}

現今內外注於て使用さる」下記ハブ用鋼材 4 種と近來 米國に於て發達したる所謂 $130 \mathrm{~kg}(\mathrm{Ni}-\mathrm{Cr}-\mathrm{Mo})$ 鋼に就完 ヘブ用鋼材として必要なる諸性質を比較し

$\begin{array}{lcrrrrrr} & & C & C r & N i & M o & I & W \% \\ ※ C r-M o & \text { 铜 } & 0.3 & 1.2 & - & 0.5 & - & - \\ C r-V & " \prime & 0.3 & 1.0 & - & - & 0.1 & - \\ ※ N i-C r & " & 0.3 & 1.2 & 3.0 & <0.65 & <0.25 & <10 \\ N i-C r & " & 0.3 & 0.5 & 4.5 & - & - & - \\ ※ N i-C r-M o & \text { " } & 0.45 & 0.8 & 17 & 0.2 & - & -\end{array}$

就中 $130 \mathrm{~kg}$ 鋼を主とし※印の鋼材飞就て鉛造試驗 熱處理 飞於汀万質量效果及燒戻脆性 静的並儿動的機械的性質等 に關する實驗結果を述べ 最後に上記の5 種銅材による固 定節プロペラハブ鈮造品の機械試驗成績を比較對照し新本

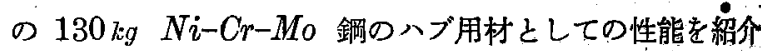
せんとするもの市

\section{7）車軸材に現れたる疪に就ての研究}

日本製鐵會社八幡製雗所 金 森 九 郎

日本全國《於りる汽車 電車の車軸は殆んど當課錳鋼工 場代て製作して居るが其中症不合格となるもの甚だ多く 年間全生產車軸の $9 \%$ 前後 (乃方約 1 万月の生產額化相 䓨する)を占为て居る 此現狀任つき今沦根本的な研究が されて居なかったので次の諸項目に亘り調查研究せり

1 緒 論
2 統計上より見をる㖢車軸

3 疵の種類

4 淽の性情

5 症の原因及びその對策

6 結 び

\section{8）鋼板の加熱絞りの際に發生する表面龜裂に就て}

厚板又は中板を强度飞加熱絞り作業する場合飞例へば汽 䌯用エンドプレートヌ怕自動車用デスクプレートの如きも

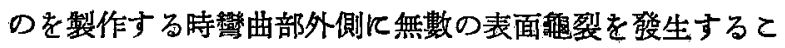

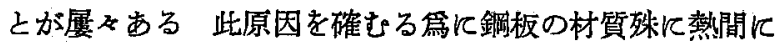
於ける諸性質並に種をの瓦斯中に於ける酸化變質狀態を試 驗し佾實地加工狀態及加工中に發生せる瘷の槕樣を調查し え其結果は表面呬裂の原因は鋼板の材質飞も依るが主とし て燒過加工に徏るもので郎ち加熱に際し表面を酸化變質さ 世或はあまりに高温度でプレスする爲である故之を防止す
日本製鐵會社八幡梨鐵所 森 寺 一 雄

るには還元焻を選び材料の酸化變質に注意し又加熱濫度法 $700 \sim 900^{\circ} \mathrm{C}$ の範圍とし出來得れば下限の溫度老可とする 向村質上から性銅 硫黄 酸素等の赤熱脃性を起させる樣落 不純物をなるべく少くし或は板の表面を研磨する等の手入 ○一方法である

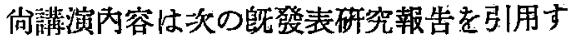

1 汽罐用厚板の表面裂洊の研究。

昭和 11 年受付研究，第 56 號 自動車用デイ、スク用鋼板不良品調查． 
、銅鋼の屈曲試驗之表面酯裂

\section{9）學振19小委員會の維鍊作業稱呼及び鍛造比表示方式に就て（前刷要り）}

日本學術振興會第 19 小委員會委員長

東京帝國大學名譽敉授 工學博士 俵 國 一

日本學街振興會第 19 小委員會（特殊鋼材）は特殊鋼材 各種作業の名稱又は比率の表し方が區々である そこで種 に起る缺點の原因 調查又は之が防止方法を研究するを目、調查し研究した上 現用せられたもの」內比较的に多數

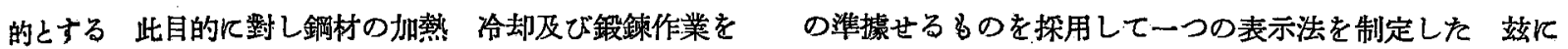
兑分に注意せねばならぬ 小委員會に於ては先づ鉣鍊作業 之を發表して一般の工場が之に據られんてをを希䍿する次 の調查を試みたるに本邦內各工場に於て現に使用せらる」＼cjkstart第でする 